\author{
Jacek Górecki ${ }^{\text {a) }}$ \\ (D) https://orcid.org/0000-0002-0812-1654
}

\title{
Statut spadkowy w postępowaniu dotyczącym podatku od spadku Glosa do wyroku Naczelnego Sądu Administracyjnego z dnia 16 maja 2019 r., II FSK 1811/18
}

\begin{abstract}
The Supreme Administrative Court has correctly adjudicated that without determining which inheritance law is applicable to the inheritance from the testator, the tax authority cannot categorically claim that an heir subject to inheritance and donation tax acquired the ownership of things or rights by inheritance at the time of the testator's death. The ruling of the Supreme Administrative Court is also an opportunity to take a broader look at the provisions of the Act of the 28th of July 1983 on inheritance and donation tax which go beyond the issues covered by this jurisdiction. That act also raises other issues the resolution of which requires the application of conflict-of-law rules or, at the very least, of the methods of qualification specific to private international law.

The position adopted by the Supreme Administrative Court in this verdict should contribute to the increase of the interest of tax authorities in conflict-of-law issues. Inheritance and donation tax is a public levy with which, due to the nature of the legal events covered by it, there are cases with the so-called „foreign element”. These are also of interest to the conflict-of-law rules. When considering them, as follows from the ruling of the Supreme Administrative Court, it is necessary to refer not only to our own (Polish) provisions of civil law, but also, by applying appropriate conflict-of-law rules, to the provisions of foreign civil law.
\end{abstract}

Keywords: inheritance - acquisition of inheritance — inheritance tax — tax exemption — citizenship — place of residence — place of permanent residence

a) Prof. dr hab., Uniwersytet Śląski w Katowicach. 


\section{Tezy}

1. Bez określenia, jakie prawo spadkowe powinno zostać w sprawie zastosowane, organ podatkowy nie może kategorycznie twierdzić, że spadkobierca nabył własność rzeczy lub praw w drodze dziedziczenia w chwili śmierci spadkodawcy. Bez ustalenia, jakie prawo spadkowe należy stosować do określenia momentu nabycia własności rzeczy lub praw majątkowych przez spadkobiercę, przedwczesne jest kategoryczne twierdzenie organu, że podatnik nabył własność rzeczy lub praw majątkowych z chwilą śmierci spadkodawcy.

2. Stosując przepisy ustawy z dnia 28 lipca 1983 r. o podatku od spadków i darowizn w zakresie zwolnienia podatkowego przewidzianego w art. 4a ust. 1 pkt 1, istnieje konieczność uwzględnienia specyfiki obcego prawa spadkowego, które może określać nie tylko odrębny moment nabycia praw własności majątku spadkowego, lecz również odmienny sposób udokumentowania nabycia tych praw. Według prawa polskiego, udokumentowanie nabycia majątku w drodze dziedziczenia następuje w drodze postanowienia sądu stwierdzającego nabycie spad$\mathrm{ku}$, poświadczenia dziedziczenia bądź europejskiego poświadczenia dziedziczenia $i$ od tych zdarzeń ustawodawca nakazuje liczyć termin do złożenia oświadczenia. Jeżeli jednak w państwie, którego prawo jest decydujące dla określenia chwili nabycia majątku spadkowego, następuje to $\mathrm{w}$ drodze inaczej udokumentowanej czynności, bieg terminu do zgłoszenia oświadczenia uprawniającego do zwolnienia podatkowego powinien być liczony od daty tej czynności. Tylko przy przyjęciu takiego poglądu podatnik będzie mógł skorzystać ze zwolnienia podatkowego określonego w art. 4 ust. 1 pkt 1 ustawy z dnia 28 lipca 1983 r. o podatku od spadków i darowizn. Zrealizowany zostanie również $\mathrm{w}$ ten sposób społeczny cel wprowadzenia omawianego zwolnienia, którym było zapewnienie szczególnej ochrony majątku najbliższej rodziny. 


\section{Glosa}

\section{Uwagi wprowadzające}

W wyroku z dnia 16 maja 2019 r. (II FSK 1811/18) NSA zajął się zagadnieniami kolizyjnoprawnymi, które pojawiły się $\mathrm{w}$ związku z koniecznością przesądzenia o możliwości powołania się na zwolnienie podatkowe przewidziane w art. 4a ust. 1 pkt 1 ustawy z dnia 28 lipca 1983 r. o podatku od spadków i darowizn [dalej: u.p.s.d.] ${ }^{1}$. W rozpatrywanej sprawie istotną dla rozstrzygnięcia okolicznością okazało się ustalenie chwili przejścia składników spadku na spadkobierców oraz chwili, od której należy liczyć początek biegu terminu do złożenia zgłoszenia umożliwiającego skorzystanie ze zwolnienia z podatku od spadków i darowizn. Obie te kwestie NSA powiązał z zastosowaniem statutu spadkowego.

W sprawie niesporne było, że spadkodawca stale zamieszkały w Wielkiej Brytanii zmarł 15 grudnia 1990 r. Jego spadkobierczyni (córka) otrzymała 25 listopada 2015 r. dokumenty, z których wynikało, że Sąd w Zjednoczonym Królestwie Wielkiej Brytanii wydał 2 czerwca 2014 r. orzeczenie o nabyciu przez nią udziału w spadku. Jednak dopiero 18 października 2016 r. dowiedziała się, w jakiej wysokości spadek otrzymała, potwierdzając to wydrukiem z rachunku bankowego. Zgodnie bowiem z prawem brytyjskim, w momencie śmierci spadkodawcy spadkobiercy ustawowi nie nabywają majątku spadkowego, lecz przechodzi on we władanie zarządcy spadku wyznaczonego przez sąd ${ }^{2}$.

Dyrektor Izby Administracji Skarbowej w R., decyzją z 20 czerwca 2017 r., utrzymał w mocy decyzję Naczelnika Pierwszego Urzędu Skarbowego w R. z 17 lutego 2017 r., ustalającą dla spadkobierczyni zobowiązanie podatkowe w podatku od spadków i darowizn z tytułu dziedziczenia po jej ojcu. W uzasadnieniu decyzji wskazano, że pomimo złożenia stosownego oświadczenia, nie może ona skorzystać ze zwolnienia określonego $\mathrm{w}$ art. $4 \mathrm{a}$ ust. 1 u.p.s.d. Jak wynika bowiem $\mathrm{z}$ art. 3 ust. 1 ustawy z dnia 16 listopada 2006 r. o zmianie ustawy o podatku od spadków i darowizn oraz ustawy o podatku od czynności cywilnoprawnych ${ }^{3}$, zwolnienie to dotyczy nabycia własności rzeczy lub praw majątkowych, które nastąpiło po 1 stycznia 2007 r. Tymczasem ojciec spadkobierczyni zmarł

1 T.j. Dz.U. 2019, poz. 1813 ze zm.

${ }^{2}$ Szerzej zob. K. Osajda, Ustanowienie spadkobiercy $w$ testamencie $w$ systemach prawnych „common law” $i$,civil law”, C.H. Beck, Warszawa, 2009, s. 236 i n.

${ }^{3}$ Dz.U. nr 222, poz. 1629. 
15 grudnia 1990 r. Powyższa decyzja została uchylona przez Wojewódzki Sąd Administracyjny w Rzeszowie wyrokiem z 31 stycznia 2018 r. (I SA/Rz 560/17). W motywach tego rozstrzygnięcia WSA wskazał, że w sprawie nie została wyjaśniona kwestia obywatelstwa ojca spadkobierczyni. Nie pozwala to ustalić, jakie prawo spadkowe powinno mieć $\mathrm{w}$ sprawie zastosowanie i w konsekwencji nie wiadomo, kiedy nastąpiło nabycie własności w drodze dziedziczenia, co ma znaczenie dla możliwości zastosowania zwolnienia przewidzianego w art. 4 a ust. 1 u.p.s.d.

W skardze kasacyjnej skierowanej do NSA Dyrektor Izby Administracji Skarbowej w R. wyrokowi WSA zarzucił m.in. naruszenie:

- art. 2 u.p.s.d. w zw. z art. 924 i 925 k.c. przez ich niezastosowanie i przyjęcie, że rozstrzygnięcie statutu spadkowego ma kluczowe znaczenie dla ustalenia, kiedy doszło do nabycia mienia tytułem spadkobrania, podczas gdy nabycie własności rzeczy lub praw majątkowych następuje $\mathrm{z}$ chwilą otwarcia spadku, tj. $\mathrm{z}$ chwilą śmierci spadkodawcy;

- art. 3 ust. 1 ustawy z dnia 16 listopada 2006 r. o zmianie ustawy o podatku od spadków i darowizn oraz ustawy o podatku od czynności cywilnoprawnych przez jego błędną wykładnię i przyjęcie, że nabycie własności rzeczy lub praw majątkowych z zagranicy wymaga określenia momentu przejścia własności na rzecz spadkobierczyni, podczas gdy nabycie spadku, o którym mowa w tym przepisie, oznacza nabycie praw rzeczy lub praw majątkowych $\mathrm{z}$ chwilą otwarcia spadku, tj. z chwilą śmierci spadkodawcy;

— art. 4a ust. 1 pkt 1 u.p.s.d. przez błędną wykładnię i zastosowanie przez przyjęcie, że moment nabycia spadku należy oceniać na podstawie przepisów prawa właściwego dla spadkodawcy, podczas gdy wskazany przepis nie wprowadza żadnych wyjątków w jego stosowaniu $\mathrm{w}$ odniesieniu do nabyć z zagranicy; niezależnie od różnych reżimów prawa polskiego i brytyjskiego definicje zawarte w tym przepisie odnoszą się zarówno do spadku nabytego w Polsce, jak i za granicą.

Rozpatrując skargę kasacyjną, NSA swe kolizyjnoprawne rozważania oparł na uchylonym już art. 64 ustawy z dnia 4 lutego 2011 r. - Prawo prywatne międzynarodowe [dalej: p.p.m.] ${ }^{4}$, ale podobne zagadnienia powstają także na tle przepisów aktualnie obowiązującego rozporządzenia Parlamentu Europejskiego i Rady (UE) nr 650/2012 z dnia 4 lipca 2012 r. w sprawie jurysdykcji, prawa właściwego, uznawania i wykonywania orzeczeń, przyjmowania i wykonywania dokumentów urzędowych dotyczących dziedziczenia oraz $\mathrm{w}$ sprawie ustanowienia europejskiego

\footnotetext{
${ }_{4}^{4}$ T.j. Dz.U. 2015, poz. 1792 ze zm.
} 
poświadczenia spadkowego [dalej: rozp.sp.] ${ }^{5}$, dlatego mają one istotny walor praktyczny i będą rzutować na sposób stosowania przepisów u.p.s.d. przez organy podatkowe i sądy administracyjne ${ }^{6}$. Należy jednak zauważyć, że z uwagi na chwilę śmierci spadkodawcy NSA powinien $\mathrm{w}$ swych kolizyjnoprawnych rozważaniach uwzględniać przepisy ustawy z dnia 12 listopada 1965 r. - Prawo prywatne międzynarodowe ${ }^{7}$, a w szczególności jej art. $34^{8}$.

Wyrok NSA stanowi również okazję do szerszego spojrzenia na przepisy u.p.s.d. wykraczające poza kwestie objęte tym judykatem. W u.p.s.d. pojawiają się bowiem także inne zagadnienia, których rozstrzygnięcie wymaga zastosowania norm kolizyjnych albo przynajmniej metod kwalifikacji charakterystycznych dla prawa prywatnego międzynarodowego. Niektóre z nich zostaną poruszone przy okazji omawiania tez przedstawionych przez NSA.

\section{Podatek od spadków i darowizn oraz wybrane wyłączenia i zwolnienia od tego podatku}

Podatkowi od spadków i darowizn [dalej: podatek] podlega nabycie przez osoby fizyczne (niezależnie od ich obywatelstwa, miejsca zamieszkania oraz miejsca stałego pobytu) własności rzeczy znajdujących się

${ }^{5}$ Dz.Urz. UE L 201 z 27.07.2012 r., s. 107 ze zm. Zob. także art. 66a p.p.m.

${ }^{6}$ Rozporządzenie spadkowe nie ma jednak bezpośredniego wpływu na opodatkowanie spadkobrania w państwach członkowskich. Zgodnie z art. 1 ust. 1 zd. 2 rozp.sp., nie znajduje ono zastosowania do spraw podatkowych. Motyw 10. Preambuły rozp.sp. wskazuje ponadto, że to prawo państwa członkowskiego określa sposób naliczania i zapłaty podatku związanego z dziedziczeniem oraz ustala, czy przekazanie majątku spadkowego beneficjentom na podstawie rozp.sp. lub wpis tego majątku do odpowiedniego rejestru mogą być objęte podatkiem (w tej kwestii zob. także motyw 18. Preambuły rozp.sp.). Wyłączenie stosowania rozp.sp. do spraw podatkowych nie oznacza jednak, że nie może ono znaleźć zastosowania do oceny kwestii kolizyjnoprawnych, które pojawiają się w postępowaniu dotyczącym podatku od spadków i darowizn. Zob. też M. Margoński, w: Komentarze Prawa Prywatnego, T. 4B, Prawo i postepowanie spadkowe. Komentarz, red. K. Osajda, C.H. Beck, Warszawa, 2018, s. 17.

${ }^{7}$ Dz.U. nr 46, poz. 290 ze zm. Ustawa utraciła moc 16 maja 2011 r. wraz z wejściem w życie p.p.m. Zob. też art. 80 p.p.m. oraz postanowienie SN z dnia 14 lutego 2013 r., II CSK 294/12, LEX nr 1365634, w którym omówiono m.in. sposób rozstrzygania kwestii intertemporalnych dotyczących spraw spadkowych.

${ }_{8}$ Zgodnie z jego treścią, w sprawach spadkowych właściwe jest prawo ojczyste spadkodawcy z chwili jego śmierci. 
na terytorium Rzeczypospolitej Polskiej lub praw majątkowych wykonywanych na terytorium Rzeczypospolitej Polskiej, m.in. na podstawie: dziedziczenia, zapisu zwykłego, dalszego zapisu, zapisu windykacyjnego, polecenia testamentowego, a także zachowku, jeżeli uprawniony nie uzyskał go w postaci uczynionej przez spadkodawce darowizny lub w drodze dziedziczenia albo w postaci zapisu ${ }^{9}$. Natomiast zgodnie z art. 2 u.p.s.d., nabycie własności rzeczy znajdujących się za granicą lub praw majątkowych wykonywanych za granicą podlega podatkowi, jeżeli w chwili otwarcia spadku nabywca był obywatelem polskim lub miał miejsce stałego pobytu na terytorium Rzeczypospolitej Polskiej ${ }^{10}$. Przy nabyciu $\mathrm{w}$ drodze dziedziczenia obowiązek podatkowy powstaje $\mathrm{z}$ chwilą przyjęcia spadku (art. 6 ust. 1 pkt 1 u.p.s.d.). Podstawa opodatkowania, zgodnie $\mathrm{z}$ art. 7 ust. 1 u.p.s.d., ustalana jest według stanu rzeczy i praw majątkowych w dniu ich nabycia oraz na podstawie cen rynkowych z dnia powstania obowiązku podatkowego.

Wyłączenia i zwolnienia od podatku ujęte są w art. 3-4b u.p.s.d. Spośród wyłączeń na uwage zasługuje to wskazane w art. 3 pkt 1 u.p.s.d., zgodnie z którym podatkowi nie podlega nabycie własności rzeczy ruchomych $^{11}$ znajdujących się na terytorium Rzeczypospolitej Polskiej lub praw majątkowych podlegających wykonaniu na terytorium Rzeczypospolitej Polskiej, jeżeli w dniu nabycia ani nabywca, ani też spadkodawca nie byli obywatelami polskimi i nie mieli miejsca stałego pobytu na terytorium Rzeczypospolitej Polskiej. Ponadto, warto zwrócić uwagę, że zwolnienia określone $\mathrm{w}$ art. 4 ust. 1 oraz $\mathrm{w}$ art. $4 \mathrm{a}$ i art. $4 \mathrm{~b}$ u.p.s.d. stosuje się, jeżeli w chwili nabycia nabywca posiadał obywatelstwo polskie lub obywatelstwo jednego z państw członkowskich Unii Europejskiej, lub państw członkowskich Europejskiego Porozumienia o Wolnym Handlu (EFTA) - stron umowy o Europejskim Obszarze Gospodarczym, lub miał miejsce zamieszkania na terytorium Rzeczypospolitej Polskiej, lub terytorium takiego państwa. Oznacza to, że obywatel państw innych niż wymienione nie korzysta z tych zwolnień, chyba że w chwili nabycia miał on miejsce zamieszkania na terytorium Rzeczypospolitej Polskiej lub terytorium jednego z wymienionych państw. Należy też zauważyć, że

${ }^{9}$ Dalsze rozważania zostaną ograniczone do zagadnień związanych z opodatkowaniem nabycia własności rzeczy i innych praw majątkowych, które następuje na podstawie dziedziczenia.

10 Szerzej o transgranicznym opodatkowaniu spadków i darowizn zob. J.K. Szczepański, Opodatkowanie transgranicznych spadków i darowizn, Wydawnictwo Naukowe UAM, Poznań, 2017, passim. Zob. także K. Chustecka, Podatek od spadków i darowizn. Praktyka i orzecznictwo, Difin, Warszawa, 2010, s. 49 i n.

${ }^{11}$ Wyłączenie to nie odnosi się zatem do nieruchomości położonych na terytorium Rzeczypospolitej Polskiej. 
ustawodawca, określając okoliczności, od których zależy powstanie omawianego obowiązku podatkowego, posługuje się zarówno pojęciem miejsca stałego pobytu, jak i pojęciem miejsca zamieszkania, co pośrednio wskazuje, że nie należy tych pojęć utożsamiać. Ponadto, dla dalszych rozważań istotne jest stwierdzenie, że powstanie obowiązku podatkowego nie jest zależne od tego, jakie prawo jest właściwe dla określenia kręgu spadkobierców obciążonych tym obowiązkiem, i innych kwestii związanych ze spadkobraniem, a zatem z przepisów u.p.s.d. nie wynika założenie, że obowiązek podatkowy powstaje tylko w przypadku, gdy statutem spadkowym jest prawo polskie.

Dla jasności dalszych rozważań należy jeszcze wskazać, że o obywatelstwie danej osoby fizycznej rozstrzyga prawo państwa, o którego obywatelstwo chodzi ${ }^{12}$. Pojęcie miejsca zamieszkania na terytorium Rzeczypospolitej Polskiej na użytek u.p.s.d. ustalać należy na podstawie art. 25 k.c. Jeśli chodzi o miejsce zamieszkania na terytorium innego państwa, to można brać także pod uwagę przepisy obowiązujące w tym państwie ${ }^{13}$. Natomiast pojęcie stałego pobytu odnosi się w u.p.s.d. przede wszystkim do osób niebędących obywatelami polskimi. W tym ujęciu operuje nim ustawa z 14 lipca 2006 r. o wjeździe na terytorium Rzeczypospolitej Polskiej, pobycie oraz wyjeździe z tego terytorium obywateli państw członkowskich Unii Europejskiej i członków ich rodzin ${ }^{14}$ oraz ustawa z 12 grudnia 2013 r. o cudzoziemcach $^{15}$. Nie powinno się go utożsamiać z miejscem zamieszkania ${ }^{16}$.

12 Zob. M. Pazdan, Prawo prywatne międzynarodowe, Wolters Kluwer, Warszawa, 2017, s. 69. W Polsce o obywatelstwie stanowi ustawa o obywatelstwie polskim z 2 kwietnia 2009 r., t.j. Dz.U. 2020, poz. 347. Zgodnie z art. 3 ust. 2 tej ustawy, obywatel polski nie może wobec władz Rzeczypospolitej Polskiej powoływać się ze skutkiem prawnym na posiadane równocześnie obywatelstwo innego państwa i na wynikające z niego prawa i obowiązki. W związku z tym na potrzeby u.p.s.d. osoba posiadająca obywatelstwo polskie nie może powoływać się na obywatelstwo innego państwa i z tego wywodzić np. wyłączenia stosowania wobec niej tej ustawy. Szerzej na temat ustalania obywatelstwa na użytek stosowania norm kolizyjnych zob. M. Pilich, Zasada obywatelstwa w prawie prywatnym międzynarodowym. Zagadnienia podstawowe, Lex a Wolters Kluwer business, Warszawa, 2015, s. 430 i n.

${ }^{13}$ W kwestii pojmowania miejsca zamieszkania jako łącznika norm kolizyjnych zob. M. Pazdan, Prawo..., s. 70 i n. Na tle u.p.s.d. miejsce zamieszkania odgrywa inną rolę, dlatego zasadniczo należy je ustalać na podstawie przepisów Kodeksu cywilnego, a jedynie posiłkowo stosować przepisy obowiązujące w miejscu przebywania danej osoby fizycznej.

${ }_{14}$ T.j. Dz.U. 2019, poz. 293 ze zm.

15 T.j. Dz.U. 2020, poz. 35 ze zm. Szerzej zob. K.J. Musiał, w: P. Borszowski i in., Ustawa o podatku od spadków i darowizn. Komentarz, Wolters Kluwer, Warszawa, 2018, s. 76 i n.

${ }_{16}$ Zob. jednak S. Bogucki, w: S. Bogucki i in., Podatek od spadków i darowizn. Komentarz, ODDK, Gdańsk, 2015, s. 125 i n., a także art. 25 ust. 1 ustawy z dnia 24 września 2010 r. o ewidencji ludności (t.j. Dz.U. 2019, poz. 1397 ze zm.), zgodnie z którym poby- 
Sprawa rozpatrywana przez NSA dotyczyła zwolnienia od podatku wynikającego z art. 4a u.p.s.d. Na jego podstawie zwalnia się od podatku nabycie własności rzeczy lub praw majątkowych przez małżonka, zstępnych, wstępnych, pasierba, rodzeństwo, ojczyma i macochę, jeżeli zgłoszą nabycie własności rzeczy lub praw majątkowych właściwemu naczelnikowi urzędu skarbowego $\mathrm{w}$ przypadku nabycia $\mathrm{w}$ drodze dziedziczenia - w terminie 6 miesięcy od dnia uprawomocnienia się orzeczenia sądu stwierdzającego nabycie spadku. Jeżeli dokumentem potwierdzającym nabycie własności rzeczy lub praw majątkowych jest akt poświadczenia dziedziczenia lub europejskie poświadczenie spadkowe, termin 6 miesięcy do zgłoszenia tego nabycia właściwemu naczelnikowi urzędu skarbowego liczy się od dnia zarejestrowania aktu poświadczenia dziedziczenia lub wydania europejskiego poświadczenia spadkowego. Jeżeli nabywca dowiedział się o nabyciu własności rzeczy lub praw majątkowych po upływie powyższych terminów, zwolnienie stosuje się, gdy nabywca zgłosi te rzeczy lub prawa majątkowe naczelnikowi urzędu skarbowego nie później niż w terminie 6 miesięcy od dnia, w którym dowiedział się o ich nabyciu, oraz uprawdopodobni fakt późniejszego powzięcia wiadomości o ich nabyciu ${ }^{17}$. Dla zastosowania wskazanego zwolnienia nie ma znaczenia miejsce położenia rzeczy należących do spadku oraz miejsce wykonywania praw majątkowych objętych spadkiem. Mogą być one położone/wykonywane zarówno na terytorium Rzeczypospolitej Polskiej, jak i za granicą.

tem stałym jest zamieszkanie w określonej miejscowości pod oznaczonym adresem z zamiarem stałego przebywania.

${ }_{17}$ Podobnie ukształtowane w art. 4b u.p.s.d. zostało zwolnienie od podatku w związku z nabyciem w drodze dziedziczenia własności przedsiębiorstwa osoby fizycznej lub udziału w nim. Można z niego skorzystać pod warunkiem: 1) zgłoszenia przez nabywce nabycia własności przedsiębiorstwa lub udziału w nim właściwemu naczelnikowi urzędu skarbowego w terminie 6 miesięcy od dnia uprawomocnienia się orzeczenia sądu stwierdzającego nabycie spadku, zarejestrowania aktu poświadczenia dziedziczenia lub wydania europejskiego poświadczenia spadkowego; 2) prowadzenia tego przedsiębiorstwa przez nabywcę przez okres co najmniej 2 lat od dnia jego nabycia. 


\section{Zagadnienia kolizyjnoprawne wpływające na powstanie obowiązku podatkowego oraz istnienie podstaw do zwolnienia z niego albo zastosowania wyłączenia}

$\mathrm{Na}$ tle powyżej zarysowanego stanu prawnego pojawia się szereg zagadnień, które należy rozstrzygnąć, aby przesądzić o powstaniu obowiązku podatkowego ciążącego na spadkobiercach oraz istnieniu podstaw do zwolnienia z niego albo zastosowania wyłączenia. Do najistotniejszych spośród nich zaliczyć należy ustalenie:

- zawartości spadku,

- miejsca położenia składników spadku,

- statutu spadkowego,

- chwili otwarcia spadku,

- kręgu spadkobierców oraz chwili nabycia przez nich składników spad$\mathrm{ku}$,

- obywatelstwa, miejsca zamieszkania, miejsca stałego pobytu spadkodawcy i spadkobierców,

- chwili przyjęcia spadku,

- chwili uprawomocnienia się orzeczenia sądu stwierdzającego nabycie spadku, zarejestrowania aktu poświadczenia dziedziczenia lub wydania europejskiego poświadczenia spadkowego.

Ponadto, w przypadku stosowania zwolnienia z art. 4a u.p.s.d. istotne jest ustalenie kręgu osób, które mogą z tego zwolnienia skorzystać. Do osób tych zaliczono: małżonka, zstępnych, wstępnych, pasierba, rodzeństwo, ojczyma i macochę. Na tym tle także wyłonić się mogą zagadnienia kolizyjnoprawne związane z ustaleniem prawa właściwego dla przesądzenia o tym, czy osoba ubiegająca się o zastosowanie względem niej zwolnienia podatkowego była ze spadkodawcą związana stosunkami rodzinnoprawnymi uzasadniającymi to zwolnienie (małżeństwo, pokrewieństwo, powinowactwo). W związku z tym pojawia się wątpliwość, czy organ podatkowy dla rozstrzygnięcia tych kwestii powinien stosować własne prawo materialne (polskie), czy też na podstawie norm kolizyjnych z p.p.m. ustalić prawo właściwe dla danego stosunku i rozstrzygać zgodnie z tym prawem. Trafny jest ten ostatni punkt widzenia. Należy jednak zwrócić uwagę, że w przypadku, gdy do określenia kręgu spadkobierców dojdzie za granicą (np. w europejskim poświadczeniu spadkowym ${ }^{18}$ ),

${ }^{18}$ Szerzej na temat europejskiego poświadczenia spadkowego zob. np.: J. Górecki, Europejskie poświadczenie spadkowe - nowy sposób potwierdzania praw do majatku 
to może się okazać, że np. małżonek dziedziczący z ustawy po spadkodawcy, według prawa właściwego ustalonego na podstawie p.p.m., nie jest małżonkiem i nie skorzysta ze zwolnienia, o którym mowa w art. 4 a u.p.s.d. Zagraniczny organ dla przesądzenia, kto jest małżonkiem dziedziczącym z ustawy po spadkodawcy, zastosuje bowiem prawo właściwe ustalone na podstawie własnych norm kolizyjnych, które doprowadzić mogą do stosowania innego niż według p.p.m. prawa materialnego miarodajnego dla ustalenia, kto w chwili śmierci spadkodawcy był jego małżonkiem. Organy podatkowe mogą zatem autonomicznie ustalać istnienie stosunku łączącego spadkodawcę ze spadkobiercą ubiegającym się o zwolnienie podatkowe nawet wówczas, gdy stosunek ten stanowił podstawę dla dziedziczenia ustawowego przez danego spadkobiercę. Jeśli spadkobranie następuje na podstawie testamentu, to jego podstawy bezpośrednio nie stanowi taki stosunek, ale powołanie spadkobiercy do dziedziczenia w testamencie. Wówczas na użytek przepisów u.p.s.d. organ podatkowy powinien przesądzić o istnieniu stosunku rodzinnego uzasadniającego zwolnienie, o które ubiega się spadkobierca. Oprzeć należy się wtedy na prawie właściwym ustalonym na podstawie norm kolizyjnych zamieszczonych w p.p.m.

Przechodząc do wyszczególnionych powyżej zagadnień, rozpocząć należy od tego, że zgodnie z powszechnie przyjętym poglądem zawartość spadku (dziedziczność składników majątku spadkodawcy) ustala się na podstawie przepisów prawa właściwego dla własności i innych praw majątkowych należących w chwili śmierci do spadkodawcy ${ }^{19}$. I tak, prawo właściwe dla stwierdzenia dziedziczności praw rzeczowych ustalać należy na podstawie art. 41 p.p.m., a w przypadku praw własności intelektualnej powinno się to uczynić zgodnie z art. 46 p.p.m. Zatem to przepisy odpowiedniego prawa właściwego, a nie statut spadkowy, przesądzają zasadniczo o tym, jak ukształtuje się zawartość spadku, którego nabycie jest objęte podatkiem. Statut spadkowy może jednak doprowadzić do wyłączenia niektórych składników ze spadku ${ }^{20}$.

Ustawa o podatku od spadków i darowizn posługuje się pojęciem „rzeczy znajdujące się na terytorium Rzeczypospolitej Polskiej” oraz „rzeczy znajdujące się za granicą”. Ustalenie tego, czy w konkretnym przypadku

spadkowego, „Rejent” 2015, nr 9, s. 9 i n.; M. Załucki, w: Unijne rozporzqdzenie spadkowe $\operatorname{Nr}$ 650/2012. Komentarz, red. M. Załucki, C.H. Beck, Warszawa, 2018, s. 334 i n..; A. Köhler, in: Internationales Erbrecht, Hrsg. W. Gierl et al., Nomos, Baden Baden, 2020, s. $138 \mathrm{i} \mathrm{n.}$

19 Zob. np. J. Pazdan, w: System Prawa Prywatnego, T. 20C, Prawo prywatne międzynarodowe, red. M. Pazdan, C.H. Beck, Warszawa, 2015, s. 698; M. Pazdan, w: Prawo prywatne międzynarodowe. Komentarz, red. M. Pazdan, C.H. Beck, Warszawa, 2018, s. 1181.

${ }^{20}$ Dotyczy to np. przedmiotu objętego zapisem windykacyjnym, dla którego statutem spadkowym jest prawo polskie. 
chodzi o rzecz, a nie inny przedmiot majątkowy, i czy znajduje się ona na terytorium Rzeczypospolitej Polskiej albo za granicą powinno następować według podobnych zasad jak w przypadku ustalania miejsca położenia rzeczy jako przedmiotu praw rzeczowych na tle art. 41 p.p.m. ${ }^{21}$ Jeśli chodzi o inne niż rzeczy składniki spadku, to u.p.s.d. operuje w odniesieniu do nich pojęciem miejsca „wykonywania praw majątkowych”. W związku z tym pojawia się pytanie, czy należy to pojęcie rozumieć analogicznie do miejsca położenia prawa, o którym mowa w art. 41 p.p.m..$^{22} \mathrm{~W}$ odniesieniu do innych niż własność praw rzeczowych można przyjąć, że miejsce położenia przedmiotu praw rzeczowych pokrywa się z miejscem wykonywania tych praw. Jeśli chodzi o inne prawa majątkowe, ustalenie miejsca ich wykonywania może być niejednoznaczne. Przykładowo, dla praw związanych z prawami udziałowymi w spółkach za miejsce ich wykonywania można uznać miejsce siedziby spółki, a w przypadku wierzytelności wynikającej z umowy miejsce wskazane w jej treści jako miejsce spełnienia świadczenia, a w braku takiego wskazania - miejsce ustalone na podstawie prawa właściwego dla danej wierzytelności. Nie jest też jasne, czy ustalając miejsce wykonywania prawa powinno się brać pod uwagę wykonywanie go przez spadkodawcę, czy przez jego następców prawnych. Ponieważ w u.p.s.d. mowa o nabyciu „praw majątkowych wykonywanych”, należy przyjąć, że są to prawa, które były lub przynajmniej mogły być wykonywane przez spadkodawcę i to miejsce faktycznego albo przynajmniej prawdopodobnego wykonywania tych praw przez niego powinno przesądzać o tym, czy były one wykonywane na terytorium Rzeczypospolitej Polskiej, czy za granicą. Natomiast nie jest w tym zakresie istotne miejsce wykonywania tych praw przez ich nabywców (np. spadkobierców).

Statut spadkowy ustala się aktualnie na podstawie rozp.sp. Znajduje ono zastosowanie, jeśli śmierć spadkodawcy nastąpiła po 16 sierpnia 2015 r. Prawo właściwe w sprawach spadkowych ustalone na podstawie rozp.sp. stosuje się niezależnie od tego, czy jest to prawo państwa, w którym rozp.sp. obowiązuje (art. 20 rozp.sp.) ${ }^{23}$. Statut spadkowy wyznaczyć może spadkodawca, dokonując wyboru prawa (art. 22 rozp.sp.). W razie braku wyboru prawa prawem właściwym dla spraw spadkowych jest zasadniczo prawo państwa, w którym spadkodawca miał miejsce zwykłe-

${ }^{21}$ Szerzej zob. J. Górecki, w: Prawo prywatne międzynarodowe. Komentarz, red. M. Pazdan..., s. 381-382. Zob. jednak P. Borszowski, w: P. Borszowski i in., Ustawa o podatku..., s. 22 i n., który wywodzi, że pojęcie rzeczy należy rozumieć w znaczeniu przyjętym w Kodeksie cywilnym. Podobnie A. Cudak, w: S. Bogucki i in., Podatek od spadków..., s. 34 i n.

22 Zob. M. Pazdan, Prawo..., s. 265; J. Górecki, w: Prawo prywatne międzynarodowe. Komentarz, red. M. Pazdan..., s. 382-383.

${ }^{23}$ Zob. też art. 34 rozp.sp. 
go pobytu w chwili śmierci (art. 21 ust. 1 rozp.sp.). ${ }^{24}$. Zakres zastosowania statutu spadkowego określa art. 23 rozp.sp., wskazując, że podlega mu ogół spraw dotyczących spadku i jednocześnie wyliczając przykładowo te sprawy ${ }^{25}$. Zaliczono do nich m.in.: chwilę otwarcia spadku ${ }^{26}$, określenie spadkobierców (w tym ich zdolność dziedziczenia ${ }^{27}$ ) i ich udziałów w spadku, przejście na nich składników spadku, warunki i skutki przyjęcia spadku ${ }^{28}$. W'śód tych spraw nie wymieniono jednak kwestii związanych ze stwierdzeniem praw do spadku, o czym jeszcze poniżej.

Statut spadkowy rozstrzyga m.in. o tym, kiedy dochodzi do nabycia przez spadkobierców składników spadku. Tę kwestię należy omówić szerzej, gdyż jak trafnie zauważył NSA chwila ta przesądza także o możliwości skorzystania ze zwolnień przewidzianych w u.p.s.d. Według stanu $\mathrm{z}$ tej chwili ocenia się bowiem, czy spadkobierca posiadał obywatelstwo polskie lub obywatelstwo jednego z państw członkowskich Unii Europejskiej, lub państw członkowskich Europejskiego Porozumienia o Wolnym Handlu (EFTA) - stron umowy o Europejskim Obszarze Gospodarczym, lub miał miejsce zamieszkania na terytorium Rzeczypospolitej Polskiej lub terytorium takiego państwa. Przyjęte m.in. w Polsce rozwiązanie oparte na założeniu, że spadek przechodzi na spadkobiercę w chwili śmierci spadkodawcy nie jest jedynym występującym na świecie. Nabycie spadku przez spadkobierców może być uzależnione od spełnienia przez nich dodatkowych przesłanek określonych w statucie spadkowym, np.: faktyczne objęcie spadku, złożenie oświadczenia o przyjęciu spadku, wydanie przez sąd lub inny organ dokumentu potwierdzającego dziedziczenie, wpis do odpowiedniego rejestru ${ }^{29}$. Spadek może być także przed jego nabyciem przez spadkobierców poddany obligatoryjnemu zarządowi wykonywanemu przez inne osoby, np. stosowany w państwach common law system administracji spadkiem, sprawowanej przez wyzna-

${ }^{24}$ Zob. ponadto art. 21 ust. 2 rozp.sp.

${ }^{25}$ Szerzej zob. M. Margoński, w: Komentarze..., s. 38 i n.; A. Köhler, in: Internationales..., Hrsg. W. Gierl et al., s. 67 i n.

${ }^{26}$ M. Pazdan, w: Prawo..., s. 1181-1182 zwraca uwagę, że śmierć osoby fizycznej jest zdarzeniem biologicznym i jej chwilę należy ustalać zgodnie z wiedzą medyczną.

27 Zob. M. Pazdan, w: Prawo..., s. 1182.

${ }^{28}$ Oddzielnie wyznacza się prawo właściwe dla czynności prawnych zawierających rozrządzenia na wypadek śmierci, w tym powołanie spadkobierców. Zob. art. 24-27 rozp.sp. oraz M. Pazdan, Prawo..., s. 367 i n.; A. Wysocka-Bar, Prawo wtaściwe dla formy rozrzqdzeń na wypadek śmierci wedtug rozporzadzenia spadkowego, w: Nowe europejskie prawo spadkowe, red. M. Pazdan, J. Górecki, Lex a Wolters Kluwer business, Warszawa, 2015, s. 134 i n.; M. Pazdan, w: Prawo..., s. 1189 i n.

${ }^{29}$ M. Pazdan, w: Prawo..., s. 1183. Zob. także K. Peroń, Zarzad spadkiem w systemach prawnych kręgu germańskiego, „Rejent” 2006, nr 2, s. 149 i n.; K. Osajda, Ustanowienie spadkobiercy..., s. 226 i n. 
czonego administratora ${ }^{30}$, który znalazł m.in. zastosowanie w rozpatrywanej sprawie.

Dopiero po przesądzeniu, na podstawie statutu spadkowego, o chwili nabycia spadku przez spadkobiercę można przystąpić do ustalenia, czy w tej chwili posiadał on obywatelstwo polskie lub obywatelstwo jednego z państw członkowskich Unii Europejskiej, lub państw członkowskich Europejskiego Porozumienia o Wolnym Handlu (EFTA) - stron umowy o Europejskim Obszarze Gospodarczym, lub miał miejsce zamieszkania na terytorium Rzeczypospolitej Polskiej lub terytorium takiego państwa, a tym samym czy może skorzystać ze zwolnienia przewidzianego w art. 4a u.p.s.d. W efekcie tych ustaleń może okazać się, że niektórzy spośród spadkobierców mogą z tego zwolnienia skorzystać, natomiast pozostali takiej możliwości są pozbawieni.

Chwila nabycia spadku ma także znaczenie dla przesądzenia tego, w jakim zakresie nabycie spadku podlega omawianemu podatkowi. Nie podlega mu bowiem nabycie własności rzeczy ruchomych znajdujących się na terytorium Rzeczypospolitej Polskiej lub praw majątkowych podlegających wykonaniu na terytorium Rzeczypospolitej Polskiej, jeżeli w dniu nabycia ani nabywca, ani też spadkodawca nie byli obywatelami polskimi i nie mieli miejsca stałego pobytu na terytorium Rzeczypospolitej Polskiej. W związku z tym w Polsce nie podlega podatkowi nabycie należących do cudzoziemca, który nie miał w Polsce miejsca stałego pobytu, własności rzeczy ruchomych znajdujących się na terytorium Rzeczypospolitej Polskiej oraz innych praw majątkowych wykonywanych na terytorium Rzeczypospolitej Polskiej, o ile jego spadkobiercy także są cudzoziemcami, a ich miejsce stałego pobytu w chwili nabycia tych składników znajdowało się poza terytorium Rzeczypospolitej Polskiej ${ }^{31}$.

W odniesieniu do opodatkowania nabycia składników spadku, takich jak własność rzeczy znajdujących się za granicą lub prawa majątkowe wykonywane za granicą, u.p.s.d. przywiązuje wagę do chwili otwarcia spadku, a nie do chwili nabycia tych składników przez spadkobiercę. Jeżeli bowiem w chwili otwarcia spadku spadkobierca był obywatelem polskim lub miał miejsce stałego pobytu na terytorium Rzeczypospolitej Polskiej, to podlega podatkowi także nabycie przez niego wymienionych składników. W tym przypadku dla obywateli polskich będących spadkobiercami nie ma znaczenia, czy ich miejsce stałego pobytu lub miejsce

${ }^{30}$ Zob. A. Kozioł, System administracji spadku w porzqdkach prawnych państw kręgu anglosaskiego, „Rejent” 2006, nr 2, s. 119 i n.; K. Osajda, Ustanowienie spadkobiercy..., s. 236 i $\mathrm{n}$.

${ }^{31} \mathrm{~W}$ takim przypadku nie można jednak wykluczyć objęcia nabycia wymienionych praw podatkiem w państwie, którego spadkobierca jest obywatelem, lub w państwie, w którym znajduje się miejsce jego stałego pobytu. 
zamieszkania w chwili otwarcia spadku znajduje się na terytorium Rzeczypospolitej Polskiej, czy poza jej granicami. Podatkiem objęte jest więc nabycie przez nich w drodze dziedziczenia własności rzeczy znajdujących się za granicą lub praw majątkowych wykonywanych za granicą niezależnie od miejsca ich stałego pobytu lub zamieszkania $\mathrm{w}$ chwili otwarcia spadku. Z kolei spadkobierca, który nie jest obywatelem polskim, o ile $\mathrm{w}$ chwili otwarcia spadku ma miejsce stałego pobytu na terytorium Rzeczypospolitej Polskiej, zostanie objęty podatkiem z tytułu nabycia w drodze dziedziczenia własności rzeczy znajdujących się za granicą lub praw majątkowych tam wykonywanych. We wskazanych powyżej przypadkach chwilę otwarcia spadku ustalać należy na podstawie statutu spadkowego, a nie a priori zakładać, że otwarcie spadku następuje zawsze w chwili śmierci spadkodawcy, jak stanowi art. 924 k.c.

\section{Ocena stanowiska NSA}

Oddzielnym zagadnieniem poddanym analizie przez NSA było ustalenie początku biegu terminu do zgłoszenia przez spadkobiercę nabycia własności rzeczy lub praw majątkowych właściwemu naczelnikowi urzędu skarbowego. Według u.p.s.d., powinno to nastąpić w terminie 6 miesięcy od dnia uprawomocnienia się orzeczenia sądu stwierdzającego nabycie spadku. Jeżeli dokumentem potwierdzającym nabycie własności rzeczy lub praw majątkowych jest akt poświadczenia dziedziczenia lub europejskie poświadczenie spadkowe, termin 6 miesięcy do zgłoszenia tego nabycia właściwemu naczelnikowi urzędu skarbowego należy liczyć od dnia zarejestrowania aktu poświadczenia dziedziczenia lub wydania europejskiego poświadczenia spadkowego. Zgłoszenie dokonane we wskazanym terminie jest przesłanką skorzystania ze zwolnienia podatkowego $\mathrm{z}$ art. $4 \mathrm{a}$ ust. 1 pkt 1 u.p.s.d. Początek biegu terminu został określony $\mathrm{w}$ u.p.s.d. jedynie $\mathrm{w}$ odniesieniu do przewidzianych przez polskie prawo procedur potwierdzających nabycie spadku przez spadkobierców. Trafnie zauważył NSA, że za granicą udokumentowanie praw do spadku może następować na podstawie innych czynności niż te znane polskiemu prawu. W związku z tym stwierdził, że jeżeli w państwie, którego prawo jest decydujące dla określenia chwili nabycia majątku spadkowego, następuje to $\mathrm{w}$ drodze inaczej udokumentowanej czynności, bieg terminu do zgłoszenia oświadczenia uprawniającego do zwolnienia podatkowego powinien być liczony od daty tej czynności. Zdaniem NSA, tylko w razie przyjęcia takiego poglądu podatnik może skorzystać ze zwolnienia podatkowego 
określonego w art. 4a ust. 1 pkt 1 u.p.s.d. i jednocześnie zrealizowany zostanie społeczny cel wprowadzenia rozpatrywanego zwolnienia, którym było zapewnienie szczególnej ochrony majątku najbliższej rodziny.

Pogląd zaprezentowany przez NSA opiera się na błędnym założeniu, że czynności związane $\mathrm{z}$ dokumentowaniem praw do spadku podlegają statutowi spadkowemu, a jak wskazano już powyżej nie są one objęte zakresem jego zastosowania określonym w art. 23 ust. 2 rozp.sp. Owszem, jednym z założeń przyjętych w rozp.sp. jest dążenie do tego, aby rozpatrywanie spraw spadkowych (w tym stwierdzanie praw do spadku) odbywało się w państwie, którego prawo jest właściwe dla rozstrzygania tych spraw $^{32}$. Nie zawsze jednak tak być musi. Przepisy rozp.sp. regulujące jurysdykcję w sprawach spadkowych dopuszczają bowiem, aby sprawy spadkowe były rozstrzygane także przed organami innych państw, a nie wyłącznie w państwie, którego prawo jest właściwe w sprawach spadkowych ${ }^{33}$. W związku z tym przyjęte przez NSA stanowisko należałoby skorygować w taki sposób, że jeśli za granicą organ wyposażony w jurysdykcję w sprawach spadkowych udokumentował prawa do spadku w innej niż znana polskiemu prawu czynności, to bieg terminu do zgłoszenia uprawniającego do zwolnienia podatkowego $\mathrm{z}$ art. 4 a ust. 1 pkt 1 u.p.s.d. powinien być liczony od daty tej czynności, a ściślej od chwili, kiedy zgodnie $\mathrm{z}$ prawem obowiązującym w państwie jej dokonania wywołuje ona skutki prawne (w tym także na skutek uprawomocnienia lub zarejestrowania). Z uwagi na charakter omawianego postępowania podatkowego możliwość powołania się na taką czynność nie powinna być uzależniona od jej uznania w Polsce $\mathrm{w}$ trybie przyjętym dla zagranicznych orzeczeń i dokumentów, z których strona chce skorzystać w sprawach cywilnych $^{34}$. Zgodnie bowiem z art. $180 § 1$ Ordynacji podatkowej ${ }^{35}$, jako dowód $\mathrm{w}$ postępowaniu podatkowym należy dopuścić wszystko, co może przyczynić się do wyjaśnienia sprawy, a nie jest sprzeczne z prawem ${ }^{36}$. Moc dowodowa zagranicznych dokumentów urzędowych nie jest ani w Ordynacji podatkowej, ani w k.p.a. odrębnie uregulowana. Dokumenty te podlegają swobodnej ocenie dowodów dokonywanej przez organ orzekający w sprawie ${ }^{37}$.

32 Szerzej o jurysdykcji w sprawach spadkowych zob. np. K. Weitz, Jurysdykcja krajowa $w$ sprawach spadkowych $w$ świetle rozporzadzenia spadkowego, w: Nowe europejskie prawo spadkowe, red. M. Pazdan, J. Górecki..., s. 45 i n.; A. Köhler, in: Internationales..., Hrsg. W. Gierl et al., s. 35 i n.

${ }^{33}$ Zob. np. art. 10 rozp.sp.

${ }^{34}$ Zob. np. art. 39 i n. oraz art. 59 rozp.sp. albo art. 1145 i n. k.p.c.

${ }^{35}$ Ustawa z dnia 29 sierpnia 1997 r., t.j. Dz.U. 2020, poz. 1325 ze zm.

${ }^{36}$ Tak samo stanowi art. $75 § 1$ zd. 1 k.p.a.

${ }_{37}$ Zob. B. Adamiak, w: B. Adamiak, J. Borkowski, Kodeks postępowania administracyjnego. Komentarz, C.H. Beck, Warszawa, 2021, s. 531. 
W podsumowaniu należy zatem stwierdzić, że stanowisko przyjęte przez NSA w omawianym wyroku, z zastrzeżeniem wskazanej powyżej korekty, jest trafne. Powinno się ono przyczynić do zwiększenia zainteresowania organów podatkowych zagadnieniami kolizyjnoprawnymi. Podatek od spadków i darowizn jest bowiem daniną publiczną, z którą, ze względu na naturę zdarzeń prawnych nim objętych, pojawiają się sprawy z tzw. elementem obcym, stanowiące również przedmiot zainteresowania norm kolizyjnych. Przy ich rozpatrywaniu, jak wynika z wyroku NSA, nieodzowne jest sięganie nie tylko do własnych (polskich) przepisów prawa cywilnego, lecz także, poprzez zastosowanie odpowiednich norm kolizyjnych, do przepisów obcego prawa cywilnego.

\section{Bibliografia}

Adamiak B., w: B. Adamiak, J. Borkowski, Kodeks postępowania administracyjnego. Komentarz, C.H. Beck, Warszawa, 2021.

Bogucki S., w: S. Bogucki i in., Podatek od spadków i darowizn, ODDK, Gdańsk, 2015.

Borszowski P., w: P. Borszowski i in., Ustawa o podatku od spadków i darowizn. Komentarz, Wolters Kluwer, Warszawa, 2018.

Chustecka K., Podatek od spadków i darowizn. Praktyka i orzecznictwo, Difin, Warszawa, 2010.

Cudak A., w: S. Bogucki i in., Podatek od spadków i darowizn, ODDK, Gdańsk, 2015.

Górecki J., Europejskie poświadczenie spadkowe - nowy sposób potwierdzania praw do majatku spadkowego, „Rejent” 2015, nr 9.

Górecki J., w: Prawo prywatne międzynarodowe. Komentarz, red. M. Pazdan, C.H. Beck, Warszawa, 2018.

Köhler A., in: Internationales Erbrecht, Hrsg. W. Gierl, A. Köhler, L. Kroiß, H. Wilsch, Nomos, Baden Baden, 2020.

Kozioł A.: System administracji spadku w porzadkach prawnych państw kręgu anglosaskiego, „Rejent” 2006, nr 2.

Margoński M., w: Komentarze Prawa Prywatnego, T. 4B, Prawo i postepowanie spadkowe. Komentarz, red. K. Osajda, C.H. Beck, Warszawa, 2018.

Musiał K.J., w: P. Borszowski i in., Ustawa o podatku od spadków i darowizn. Komentarz, Wolters Kluwer, Warszawa, 2018.

Osajda K., Ustanowienie spadkobiercy $w$ testamencie $w$ systemach prawnych „common law” $i$,civil law”, C.H. Beck, Warszawa, 2009.

Pazdan J., w: System Prawa Prywatnego, T. 20C, Prawo prywatne międzynarodowe, red. M. Pazdan, C.H. Beck, Warszawa, 2015. 
Pazdan M., Prawo prywatne międzynarodowe, Wolters Kluwer, Warszawa, 2017.

Pazdan M., w: Prawo prywatne międzynarodowe. Komentarz, red. M. Pazdan, C.H. Beck, Warszawa, 2018.

Peroń K., Zarzad spadkiem $w$ systemach prawnych kręu germańskiego, „Rejent” 2006, nr 2.

Pilich M., Zasada obywatelstwa $w$ prawie prywatnym międzynarodowym. Zagadnienia podstawowe, Lex a Wolters Kluwer business, Warszawa, 2015.

Szczepański J.K., Opodatkowanie transgranicznych spadków i darowizn, Wydawnictwo Naukowe UAM, Poznań, 2017.

Weitz K., Jurysdykcja krajowa $w$ sprawach spadkowych $w$ świetle rozporzadzenia spadkowego, w: Nowe europejskie prawo spadkowe, red. M. Pazdan, J. Górecki, Lex a Wolters Kluwer business, Warszawa, 2015.

Wysocka-Bar A., Prawo wtaściwe dla formy rozrzqdzeń na wypadek śmierci wedtug rozporzadzenia spadkowego, w: Nowe europejskie prawo spadkowe, red. M. Pazdan, J. Górecki, Lex a Wolters Kluwer business, Warszawa, 2015.

Załucki M., w: Unijne rozporzadzenie spadkowe Nr 650/2012. Komentarz, red. M. Załucki, C.H. Beck, Warszawa, 2018. 